\title{
The effect of drying temperatures and storage of seeds on the growth of soybean seedlings ${ }^{1}$
}

\author{
Cesar Pedro Hartmann Filho ${ }^{2 *}$, André Luís Duarte Goneli², Tathiana Elisa \\ Masetto $^{2}$, Elton Aparecido Siqueira Martins², Guilherme Cardoso Oba ${ }^{2}$
}

\begin{abstract}
Drying of seeds reduces their moisture content to levels appropriate for storage. However, care in the temperatures applied in the process is necessary to avoid damage to the seeds that are dried. The aim of this study was to evaluate the effect of different drying temperatures and storage on the growth of soybean seedlings. Harvested with a moisture content of approximately $23 \%$ (w.b.), the seeds were dried at different temperatures $\left(40,50,60,70\right.$, and $\left.80{ }^{\circ} \mathrm{C}\right)$ until reaching moisture content of $12.5 \pm 0.7 \%$ (w.b.), and they were subsequently stored for 180 days in an environment without climate control. A germination test and evaluations of seedling performance were carried out every 45 days, determining the full length of the seedling and hypocotyl and root lengths, along with their respective dry matter weights. The results showed that: a) the increase in the temperature of drying air affects the physiological quality of soybean seeds, and this effect is accentuated over time, especially on root length; and b) the air temperature of $40{ }^{\circ} \mathrm{C}$ can be recommended for drying of soybean seeds in association with the storage time of 180 days under storage conditions without climate control.
\end{abstract}

Index terms: Glycine max L., germination, seed vigor, post-harvest.

\section{Temperaturas de secagem e armazenamento de sementes no crescimento de plântulas de soja}

\begin{abstract}
RESUMO - A secagem de sementes permite reduzir o teor de água a níveis adequados para o armazenamento. Porém, cuidados com as temperaturas aplicadas no processo são necessários para evitar danos às sementes submetidas à secagem. $\mathrm{O}$ trabalho foi realizado com o objetivo de avaliar o efeito de diferentes temperaturas de secagem e do armazenamento sobre o crescimento de plântulas de soja. As sementes foram colhidas com aproximadamente $23 \%$ de teor de água, e submetidas a diferentes temperaturas de secagem $\left(40,50,60,70\right.$ e $\left.80^{\circ} \mathrm{C}\right)$ até atingirem $12,5 \pm 0,7 \%$ (b.u.), sendo posteriormente armazenadas, em ambiente não controlado, durante 180 dias. A cada 45 dias foi realizado o teste de germinação e as avaliações referentes ao desempenho de plântulas, determinando-se os comprimentos total, do hipocótilo e da raiz, e ainda verificando suas respectivas massas de matéria seca. Com base nos resultados pôde-se concluir que: a) o aumento da temperatura do ar de secagem afeta a qualidade fisiológica das sementes, sendo esse efeito potencializado com o tempo de armazenamento, principalmente sobre o comprimento da raiz; b) a temperatura do ar de $40{ }^{\circ} \mathrm{C}$ pode ser recomendada para a secagem de sementes de soja, sendo associada ao período de armazenamento de 180 dias em condições não controladas.
\end{abstract}

Termos para indexação: Glycine max L., germinação, vigor de sementes, pós-colheita.

\section{Introduction}

Obtaining quality soybean seeds has always been one of the main challenges within the production system (MarcosFilho, 2013). Thus, due to this importance, there has been an incessant search for effective methods of characterizing the quality of a determined seed lot within the crop production process (Vieira et al., 2013b).
Due to the need for increasingly practical methods in regard to determination of qualitative parameters, generally because of little time available to laboratories, more dynamic tests are chosen, and thus, more elaborate evaluations, for example, an evaluation relative to initial growth of seedlings, are often not chosen. As a result, some problems observed during the seedling phase end up being overlooked, and, depending on the levels of severity, crop performance in the

${ }^{1}$ Submitted on $03 / 31 / 2016$. Accepted for publication on 08/19/2016.

${ }^{2}$ Universidade Federal da Grande Dourados, Faculdade de Ciências Agrárias, Caixa Postal 533, 79804-970 - Dourados, MS, Brasil.

*Corresponding author $<$ cphartmann21@hotmail.com> 
field and, consequently, crop yield may be affected.

The evaluation of seedling performance and structures, more specifically, the hypocotyl and the root, can provide useful results regarding seed quality, considering their ability to manifest damage in some points of the production chain, such as that generated at harvest and during the processing phase (Barbosa et al., 2014; Faria et al., 2014).

After harvest, it is common for seed lots to have moisture contents considered inadequate for safe and effective storage, such as contents higher than $12 \%$. Given this situation, there is clearly a need for reduction of this characteristic to preserve the physiological quality of seeds for at least eight months, impeding possible chemical and physical changes that may come about during storage up to sale of the seeds (Peske et al., 2013; Barrozo et al., 2014; Carvalho et al., 2016).

For efficient storage, not only good initial quality is necessary, but seeds need to have gone through drying conditions that avoid loss of physiological quality and only then be stored under what are considered to be ideal conditions, such as temperatures below $20{ }^{\circ} \mathrm{C}$ and relative humidity below $60 \%$ (França-Neto et al., 2010; Mbofung et al., 2013; Smaniotto et al., 2014). Nevertheless, when carried out without due care, both drying and storage can have a negative impact on seed quality, immediately affecting, for example, their germination and vigor through improper drying or, moreover, worsening some such detrimental effect in accordance with storage time and conditions (Deliberali et al., 2010; Ullmann et al., 2010; Schuh et al., 2011; Resende et al., 2012; Faria et al., 2014; Rathinavel, 2014; Mahjabin and Abidi, 2015; Paraginski et al., 2015).

Drying soybean seeds at temperatures of 45 and $55{ }^{\circ} \mathrm{C}$ directly affect viability, germination, and vigor of soybean seeds, with a further negative impact on the storage potential of the material. The prejudicial effect worsens the immediate problems caused by drying, especially under temperatures greater than $20{ }^{\circ} \mathrm{C}$ and relative humidities that are not controlled, which reduce the potential for nine months of seed storage to approximately four months (Surki et al., 2012).

In this context, evaluation of seedling performance is an extremely important tool because determination of parameters for growth and initial development, such as assimilation of cotyledonary reserves on the part of the embryonic axis, can portray not only the immediate effects caused by drying, but also their implications for storage, increasing reliability regarding the physiological potential of seeds at different periods. Based on the literature, the seed lots with high germination and vigor have larger seedlings that are able to accumulate more dry matter (Henning et al, 2010; Pereira et al., 2013; Pereira et al., 2015). These discoveries may be related to the fact that high vigor soybean seeds have not only greater physical integrity (as long as the drying operations were well performed (Afrakhteh et al., 2013) but also higher contents of starch, proteins, and soluble sugars and greater ability to mobilize reserves during the germination period (Henning et al., 2010).

Thus, the aim of this study was to evaluate the effects of different drying temperatures, associated with storage of seeds, on the initial growth of soybean seedlings.

\section{Materials and Methods}

Seeds of the soybean cultivar SYN 1059 RR (V-TOP) were produced under the no-till system and center pivot irrigation from January to May 2014 on the São Lourenço Farm at $22^{\circ} 11^{\prime} 58.06^{\prime} \mathrm{S}, 54^{\circ} 53^{\prime} 24.32$ ' W, and 452 meters altitude, in Dourados, Mato Grosso do Sul state, Brazil. They were analyzed at the Preprocessing and Storage of Agricultural Products Laboratory belonging to the School of Agrarian Sciences of the Federal University of Grande Dourados (UFGD) in the municipality of Dourados, MS, Brazil.

Preparation of the area involved only desiccation (Paraquat + Diuron - 400 g + 200 g.ha- ${ }^{-1}$; 2,4-Dicholorophenoxy - 806 g.ha $\left.{ }^{-1}\right)$, and the fertilization process, for its part, was carried out at the same time as sowing, using $260 \mathrm{~kg} \cdot \mathrm{ha}^{-1}$ of the fertilizer formulation $02-20-20$ (N-P-K), also containing $8 \%$ $\mathrm{Ca}, 4 \% \mathrm{~S}, 0.2 \% \mathrm{Zn}$, and $0.1 \%$ Bo. The seeds were treated with insecticides (Fipronil - 12.5 g.50 kg of seeds ${ }^{-1}$; Tiamethoxan - $17.5 \mathrm{~g} .50 \mathrm{~kg}$ of seeds ${ }^{-1}$ ) and fungicides (Metalaxil-M + Fludioxonil $-0.5 \mathrm{~g}+1.25 \mathrm{~g} .50 \mathrm{~kg}$ of seeds ${ }^{-1}$ ), and were then sown mechanically at a spacing of $0.45 \mathrm{~m}$ between the plant rows and a density of 18 seeds. $\mathrm{m}^{-1}$, obtaining a final population of 355,555 plants.ha ${ }^{-1}$.

The seeds produced were harvested manually close to the stage of physiological maturity ( $7+15$ days), according to the determination of Fehr and Caviness (1977), with a moisture content of approximately $23 \pm 0.5 \%$ (w.b.) $(0.30 \pm$ 0.005 decimal d.b.).

After that, drying occurred in an experimental fixed bed dryer, with a drying chamber of $0.080 \mathrm{~m}$ diameter by 1.0 $\mathrm{m}$ height. The experimental dryer used a set of electrical resistors as a heating source, which had a total of $12 \mathrm{~kW}$ of power and, associated with them, a centrifuge type fan of 0.75 $\mathrm{kW}$ of power, Ibram VSI-160. Temperature was controlled by a universal process controller, Novus N1200, working with a Proportional-Integral-Derivative (PID) controller. The air flow used was $0.2 \mathrm{~m}^{3} \cdot \mathrm{s}^{-1} \cdot \mathrm{m}^{-2}$, selected by a frequency inverter connected to the fan motor.

The drying temperatures used were $40,50,60,70$, and 
$80{ }^{\circ} \mathrm{C}$ to obtain seeds with moisture content of $12.5 \pm 0.7 \%$ (w.b.) $(0.14 \pm 0.007$ decimal d.b.). Drying was monitored by the gravimetric method, and loss in weight of the product was monitored in a stepwise and prudent manner, considering the final pre-established moisture content. In this step, the times required so that each drying temperature reached such a final moisture content were $230,160,112,75$, and 57 minutes, respectively. For determination of moisture contents, the laboratory oven method was used at $105 \pm 3{ }^{\circ} \mathrm{C}$ for 24 hours, with two replications of 200 seeds (approximately $25 \mathrm{~g}$ ) (Brasil, 2009). With monitoring of drying, the water reduction rate (WRR) of the soybean seeds was determined for each drying temperature used, being established by Equation 1, according to Corrêa et al. (2001), who conceive of this calculation as the amount of water that a determined product loses per unit of dry matter per unit of time.

$$
\mathrm{WRR}=\frac{\mathrm{W}_{0}-\mathrm{W}_{\mathrm{i}}}{\operatorname{DM}\left(\mathrm{t}_{\mathrm{i}}-\mathrm{t}_{0}\right)}
$$

in which,

WRR: water reduction rate, in $\mathrm{kg} \cdot \mathrm{kg}^{-1} \cdot \mathrm{h}^{-1}$;

$\mathrm{W}_{0}$ : total previous water weight, in $\mathrm{kg}$;

$\mathrm{W}_{\mathrm{i}}$ : total current water weight, in $\mathrm{kg}$;

DM: dry matter weight, in $\mathrm{kg}$;

$\mathrm{t}_{0}$ : total previous drying time, in $\mathrm{h}$; and

$\mathrm{t}_{\mathrm{i}}$ : total current drying time, in $\mathrm{h}$.

After drying, the soybean seeds were placed according to the drying treatment in non-hermetic metallic containers. These closed containers were kept in an environment with temperature and relative humidity not controlled for a period of 180 days; germination and seedling performance, along with seed moisture content, was evaluated immediately after drying and every subsequent 45 days.

Two thermo hygrometers were installed near the containers to monitor and register variations in heat and humidity in the environment during the storage period (Figure 1). Mean temperature throughout the experiment was $21.4^{\circ} \mathrm{C}$, with a maximum of $28.4{ }^{\circ} \mathrm{C}$ and minimum of $14.5{ }^{\circ} \mathrm{C}$. The mean value of relative humidity was $57.9 \%$, with a maximum of $83.4 \%$ and minimum of $47.3 \%$.

The germination test was carried out in accordance with the criteria established in the Rules for Seed Testing (Brasil, 2009). Four 50-seed subsamples for each treatment were distributed in rolls of paper toweling moistened with distilled water at two and a half times the weight of the dry paper and kept at $25{ }^{\circ} \mathrm{C}$ in a Mangelsdorf germinator. The percentage of normal seedlings was calculated eight days after the test was set up.

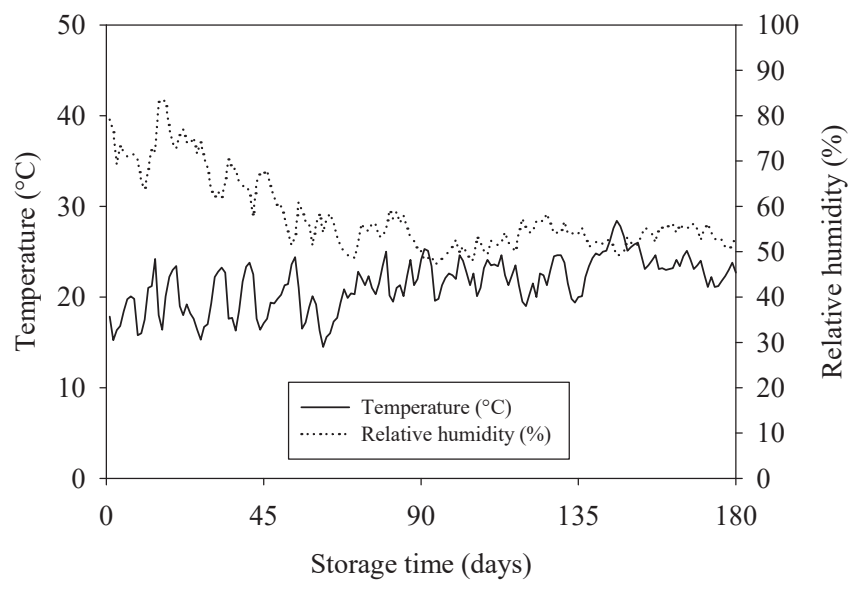

Figure 1. Mean daily values of temperature and relative humidity over 180 days of storage of soybean seeds in an environment without climate control.

Seedling performance was evaluated through determination of the length of seedlings and their structures, and through total dry matter weight and weight of the hypocotyl and roots (Nakagawa, 1999, Benincasa, 2003; Ferreira and Borghetti, 2004; Marcos-Filho, 2015).

Seedling length was determined using four 15 -seed subsamples that were arranged in two rows lengthwise on the sheets of paper toweling, which were moistened with distilled water at two and a half times the weight of the dry paper. The seeds were placed with the point of the radicle turned downward to direct seedling growth in as straight a line as possible to favor measurement of length. After this procedure, the paper rolls were arranged similar to the germination test and were placed in a Mangelsdorf germinator regulated to $25 \pm 1{ }^{\circ} \mathrm{C}$ for seven days.

Total length of the seedlings was measured from the tip of the radicle up to the point of connection of the apical bud to the stem. Length of the hypocotyl was measured from point of connection of the hypocotyl with the root up to its point of connection with the cotyledons. The length of the primary root was measured from the tip of the root up to its point of connection with the hypocotyl. All lengths were measured with a digital caliper with $0.01 \mathrm{~mm}$ resolution, and results were obtained by adding up the measurements taken of each normal seedling in each replication and then dividing by the number of normal seedlings measured; results were expressed in mm.seedling ${ }^{-1}$.

The seedlings measured in the length test were used for determination of dry matter weight (Benincasa, 2003). A scalpel was used to remove the cotyledons and to divide the seedling into hypocotyl and root. Soon after this procedure, the hypocotyls and the roots for each replication were placed separately in previously weighed aluminum containers, which, 
in turn, were placed in a previously regulated laboratory oven with circulation and renewal of air and kept at $80{ }^{\circ} \mathrm{C}$ for 24 hours (Benincasa, 2003). After this period, the samples were removed from the laboratory oven and allowed to cool in a desiccator for 20 minutes, followed by weighing on an analytic balance with $0.001 \mathrm{~g}$ resolution, thus determining the dry matter weights of the hypocotyls and roots, and the total dry matter weight. The weight obtained was divided by the number of normal seedlings, resulting in dry matter weight per seedling, expressed in mg.seedling ${ }^{-1}$.

The experiment was conducted in a $5 \times 5$ split plot arrangement, with five temperatures of drying air in the plots and five different storage periods in the split plots in a completely randomized design. To evaluate the latent effect of the drying temperatures, the data were subjected to polynomial regression analysis. The models were selected considering the magnitude of the coefficient of determination $\left(\mathrm{R}^{2}\right)$, the significance of regression by the F test, and the phenomenon under study using the Sisvar program (Ferreira, 2011).

\section{Results and Discussion}

Through curves of the water reduction rate (WRR) obtained during the drying of soybean seeds, it was observed that in accordance with higher temperatures, such as 60,70 and $80^{\circ} \mathrm{C}$, the WRR was clearly more accentuated already at the beginning of the process (Figure 2). However, over time, this rate became more homogeneous among the drying treatments since the water present at the surface of the product was gradually substituted by an evaporation front that moved inward in the product. In addition, due to the involvement of more complex mechanisms in movement of water from the inside to the outside of the seed, such as liquid diffusion and capillary action, the speed of the process declined, thus manifesting similarity of the WRR among the thermal treatments applied as of approximately 50 minutes from the start of drying.

Due to hygroscopicity of the seeds, oscillations of moisture contents were observed during storage, above all because lack of control of temperature and relative humidity conditions lead to the occurrence of phenomena such as sorption and desorption (Table 1) (Tiecker Junior et al., 2014; Bessa et al., 2015).

There was a reduction in moisture content in all the seed lots evaluated (Table 1), probably due to reduction in the values of relative humidity in the air of the environment over time (Figure 1) and possibly also due to the centesimal composition of the seeds since they are aleuro-oleaginous and tend to retain less water internally because their oil content is less hydrophilic (Dios, 1984).

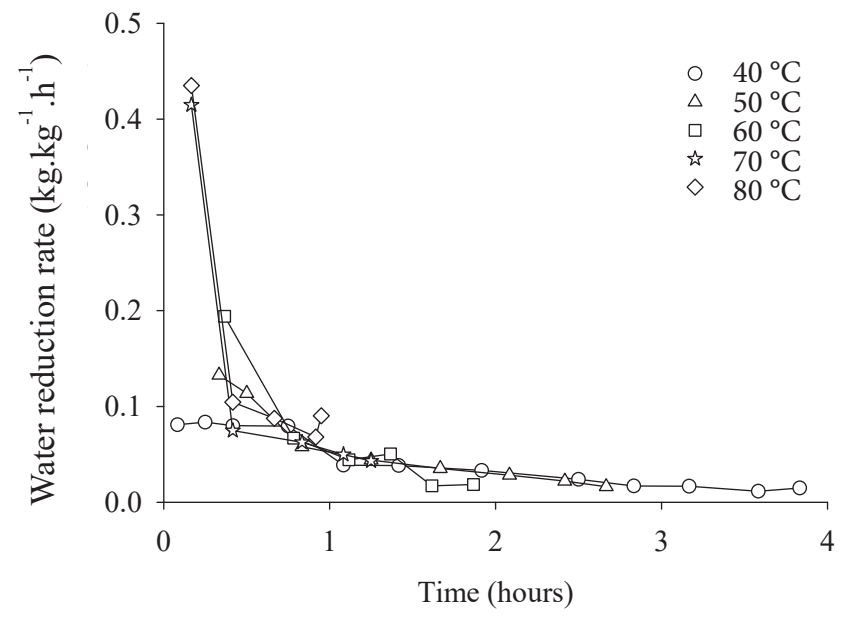

Figure 2. Water reduction rate for soybean seeds (cv. SYN $1059 \mathrm{RR})$ during the drying process at different temperatures.

Table 1. Mean values of moisture content (\% w.b.) of soybean seeds as a function of drying temperature and of storage time.

\begin{tabular}{cccccc}
\hline \multirow{2}{*}{$\begin{array}{c}\text { Storage time } \\
\text { (days) }\end{array}$} & \multicolumn{5}{c}{ Drying temperature $\left({ }^{\circ} \mathrm{C}\right)$} \\
\cline { 2 - 6 } & 40 & 50 & 60 & 70 & 80 \\
\hline 0 & 13.2 & 12.7 & 12.4 & 12.5 & 12.0 \\
45 & 13.4 & 12.8 & 12.4 & 12.6 & 12.3 \\
90 & 12.6 & 12.1 & 12.0 & 11.8 & 11.4 \\
135 & 11.1 & 10.6 & 10.6 & 10.5 & 10.2 \\
180 & 11.3 & 11.0 & 10.8 & 10.8 & 10.4 \\
\hline
\end{tabular}

For seed germination, it was observed that due to the increase in temperature of drying air, the percentage of normal seedlings already decreased immediately after drying, and this deleterious effect intensified in a linear manner over the storage time (Figure 3).

Immediately after drying, the germination observed for the temperatures of $40,50,60,70$, and $80{ }^{\circ} \mathrm{C}$ were 100,97 , 88,28 , and $1 \%$, respectively (Figure 3 ). However, due to the occurrence of this latent response, in the evaluation after 45 days, the dissimilarity between the two treatments was evident, with daily reduction in the percentage of normal seedlings caused by the temperature of $50{ }^{\circ} \mathrm{C}$ being twice that brought about by the temperature of $40{ }^{\circ} \mathrm{C}$; greater daily reductions were also observed for the temperatures of 60,70 , and $80{ }^{\circ} \mathrm{C}$.

Consequently, at the end of storage, the values of the germination observed for the temperatures of 40, 50, 60, 70, and $80{ }^{\circ} \mathrm{C}$ were $86,64,55,3$, and $1 \%$, respectively (Figure 3 ). Thus, if the parameters established by regulatory standard number 45 instituted by Brasil (2013) were adopted, which 
establishes $80 \%$ germination as the minimum limit for sale of soybean seeds, only the lot of seeds dried at $40{ }^{\circ} \mathrm{C}$ could be fit to the standard commercialization, given that the lots dried at 50 and $60^{\circ} \mathrm{C}$ lose their capacity at approximately 150 and 101 days after drying, and the others already immediately after the drying operation.

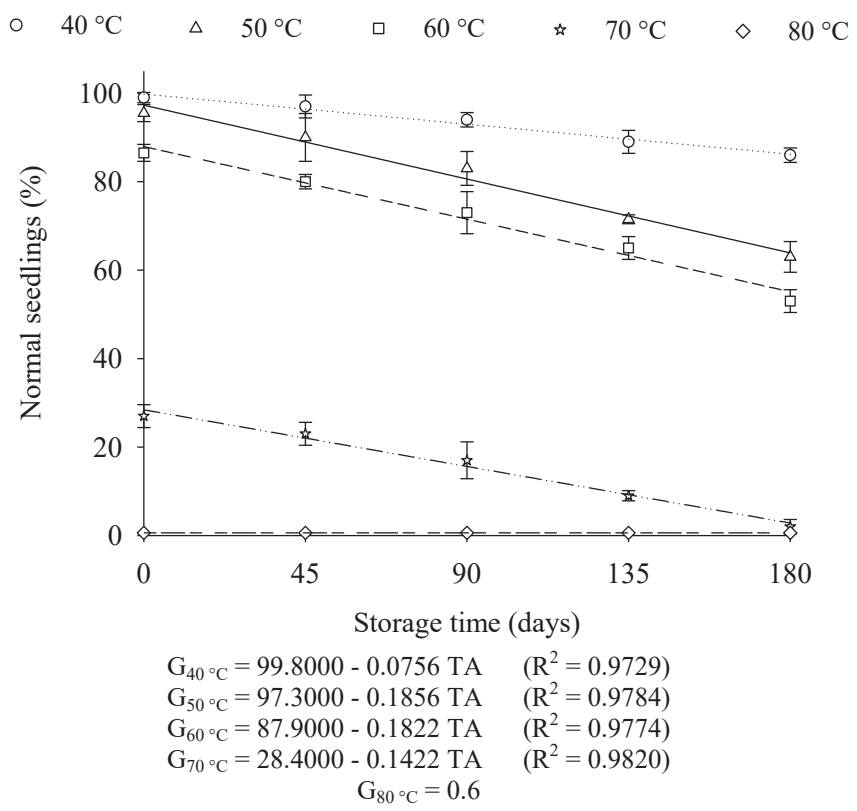

Figure 3. Results of percentage of normal seedlings for the germination test of soybean seeds as a function of drying temperature and storage time.

The effect of different drying temperatures on the physiological quality of seeds was also observed by Ullmann et al. (2015) in evaluation of sweet sorghum seeds, in which a reduction in the germination was observed in accordance with the temperature factor, especially at temperatures above $40^{\circ} \mathrm{C}$; each increase in degree of temperature led to reduction of half a percentage point in germination. As suggested by Afrakhteh et al. (2013) and also observed by Menezes et al. (2012a,b), and furthermore in this study, this is generally a result of the increase in the rate of water removal (WRR) from the product, which is stimulated by the increase in temperature of the drying air. This increase in WRR, upon creating a stark difference between the peripheral and inner part of the product, promotes the formation of seed coat cracks and microfissures in the cotyledons, affecting the quality of the seed. In addition, situations such as these can increase the susceptibility of the material to latent damage, or even worsen deterioration, thus reducing the storage potential of the product and its physiological quality (Mbofung et al., 2013).

The deleterious effect portraying the damage caused by drying in soybean seeds was also observed by Silva et al. (2007) upon finding that the use of drying temperatures higher than $40{ }^{\circ} \mathrm{C}$ led to cell damage, such as membrane disarray and leaching of solutes, mainly in the region of the embryonic axis, harmful to the development of seedlings and thus reducing the two main physiological properties, germination and vigor. In addition, as found by Vieira et al. (2013a), the initial quality of a soybean seed lot and the conditions during storage determine maintenance of seed physiological potential since undamaged seeds undergo less reduction in seed coat thickness when subjected to either storage under cold conditions $\left(10^{\circ} \mathrm{C}\right)$ or conditions already considered harmful to soybean physiological potential $\left(25^{\circ} \mathrm{C}\right)$.

Evaluations of seedling performance also manifested the negative effects of the increase in drying temperature and of storage on the physiological quality of soybean seeds. It was observed that the total length of seedlings (Figure 4a) and the length of the hypocotyl (Figure 4b) and of the root (Figure 4c) showed decreasing results in accordance with an increase in temperature of drying air, and linear degradation of seed response over the storage time.

Evaluation of the length of seedlings and their structures compared to germination percentage exhibited greater sensitivity in differentiating the lots in regard to physiological quality immediately after drying. Although it was found that both analyses were negatively affected by the drying temperatures, associated with prolongation of the storage period, for germination, the immediate difference found was evident after the application of the temperature of $60{ }^{\circ} \mathrm{C}$ (Figure 3), whereas by evaluation of the seedling characteristics, the differences between the thermal treatments applied to the seeds were immediately observable from the temperatures of 40 and $50{ }^{\circ} \mathrm{C}$ (Figure 4). According to the review of Garcia et al. (2004), thermal damages might not manifest immediate effects on germination; however, after a period of storage, seed vigor may undergo considerable reductions.

It should be noted that analysis of seedling growth and other complementary tests compose a vigor index for evaluation of soybean seed quality (Vanzolini et al., 2007), and, from the results obtained, it may be inferred that the deleterious effects of high temperatures during drying were more expressive on the growth of the shoots and root, which may have exhibited greater sensitivity to the treatments.

Increasing the temperature factor in soybean seeds, especially at temperatures above $40^{\circ} \mathrm{C}$, compromises seedling growth since an increase in drying rate leads to damages to meristematic tissues and, consequently, injured development of the embryonic axis (Afrakhteh et al., 2013). In this context, Costa et al. (1999) highlight that the greater the length of the hypocotyl, the greater the seedling capacity to emerge and overcome the resistance that may be posed by depth of sowing and/or hardened soil. 


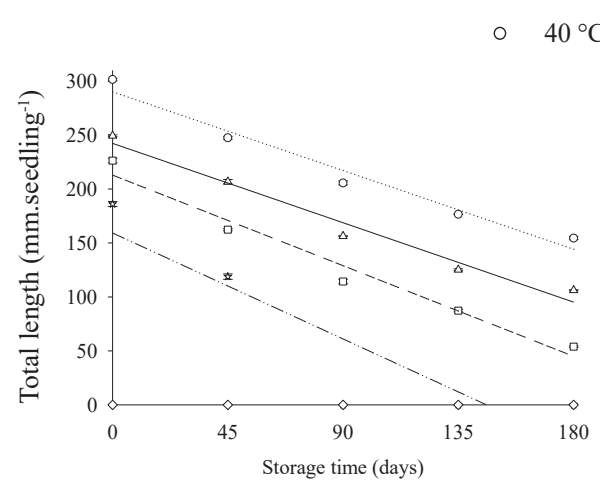

(a)

$\mathrm{TL}_{40}{ }^{\circ} \mathrm{C}=290.0844-0.8107 \mathrm{ST} \quad\left(\mathrm{R}^{2}=0.9591\right)$

$\mathrm{TL}_{50}{ }^{\circ} \mathrm{C}=242.3235-0.8174 \mathrm{ST} \quad\left(\mathrm{R}^{2}=0.9643\right)$

$\mathrm{TL}_{60}{ }^{\circ} \mathrm{C}=212.8097-0.9328 \mathrm{ST} \quad\left(\mathrm{R}^{2}=0.9597\right)$

$\mathrm{TL}_{70}{ }^{\circ} \mathrm{C}=159.1751-1.0911 \mathrm{ST} \quad\left(\mathrm{R}^{2}=0.7327\right)$

$$
\mathrm{TL}_{80}{ }^{\circ} \mathrm{C}=0
$$

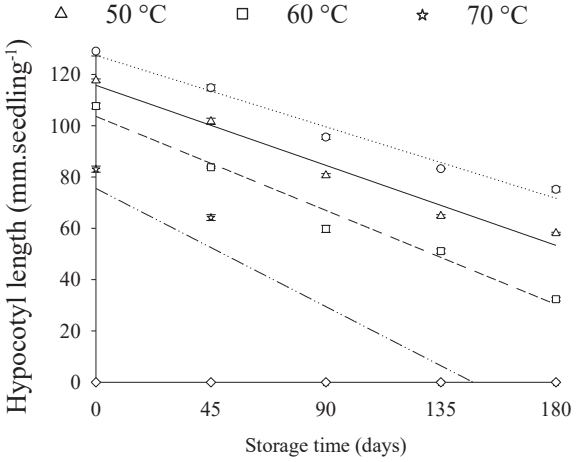

(b)

$\mathrm{HL}_{40{ }^{\circ} \mathrm{C}}=127.4350-0.3096 \mathrm{ST} \quad\left(\mathrm{R}^{2}=0.9743\right)$

$\mathrm{HL}_{50{ }^{\circ} \mathrm{C}}=115.7527-0.3466 \mathrm{ST} \quad\left(\mathrm{R}^{2}=0.9675\right)$

$\mathrm{HL}_{60}{ }^{\circ} \mathrm{C}=103.6215-0.4073 \mathrm{ST} \quad\left(\mathrm{R}^{2}=0.9687\right)$

$\mathrm{HL}_{70}{ }^{\circ} \mathrm{C}=75.5250-0.5119 \mathrm{ST} \quad\left(\mathrm{R}^{2}=0.7249\right)$

$$
\mathrm{HL}_{80}{ }^{\circ} \mathrm{C}=0
$$

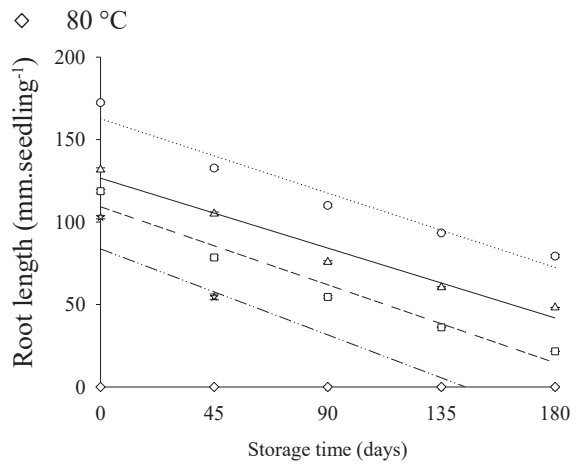

(c)

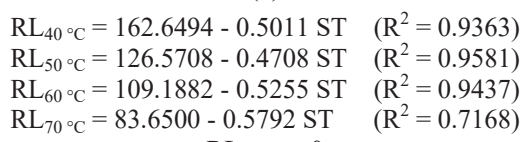

$\mathrm{RL}_{80}{ }^{\circ} \mathrm{C}=0$

Figure 4. Results of the total length of the seedling (a) and the length of its structures, the hypocotyl (b) and root (c), of soybean seeds subjected to different drying temperatures as a function of storage time.

In regard to drying temperatures of 70 and $80^{\circ} \mathrm{C}$, not only was there a response of smaller seedlings but also decreased quality of the seed lots (Figure 4). Seeds dried at $70{ }^{\circ} \mathrm{C}$, for example, led to formation of smaller seedlings and shorter total length (159.2 mm.seedling $\left.{ }^{-1}\right)$ and length of the shoots (75.5 mm.seedling $\left.{ }^{-1}\right)$ and of the root $\left(83.6 \mathrm{~mm}\right.$.seedling $\left.{ }^{-1}\right)$, but they also exhibited the highest results of latent damage, which possibly impeded formation of normal seedlings that could be measured at 150 days after the storage beginning . Drying at the temperature of $70{ }^{\circ} \mathrm{C}$ also damage the physiological quality of crambe seeds, which exhibited results analogous to those found here and the occurrence of smaller seedlings, given the higher rate of injuries to the seeds (Faria et al., 2014). The soybean seeds dried at $80{ }^{\circ} \mathrm{C}$, both immediately after drying and during storage, were not able to generate normal seedlings, indicating the harmful effects of high temperatures on the quality of soybean seeds.

Although the seedling structures exhibit similar responses in accordance with an increase in drying temperature and storage time, the susceptibility of the primary root immediately after drying and over the storage time should be noted (Figure 4c). Possibly, since the radicle is located in a region slightly more external in the seed compared to the hypocotyl, its exposure to drying and to the deterioration processes was more evident, indicating that the performance of the root constitutes a good indication in distinguishing among seed lots, as has already been proposed by Vanzolini et al. (2007) and recommended by Chauhan (1985) precisely for soybean seeds, and as observed for seeds of wheat (Maia et al., 2007), maize (Venancio et al., 2012), and papaya (Mengarda et al., 2015).

The harmful effects of drying temperatures above $40^{\circ} \mathrm{C}$, along with seed storage, were also observed in the dry matter weight of seedlings and their structures since the dry matter weights of the seedling, the hypocotyl, and the root coming from seeds dried at $40{ }^{\circ} \mathrm{C}$ were greater by 5.6, 3.3, and 2.3 mg.seedling ${ }^{-1}$ in relation to the results observed for the temperature of $50{ }^{\circ} \mathrm{C}$ (Figure 5).

By the multiplicative coefficients of the equations fitted to the data observed for total dry matter weight of the seedling, it was found that the immediate effect arising from increasing the temperature of drying air was the determining factor in maintaining the quality of seeds during storage because, in accordance with the increase in temperature, there was greater latent loss of total accumulated dry matter (Figure 5). Thus, evaluation allowed confirmation of the ability of the test in showing both the immediate effects and latent effects caused by an increase in the temperature of drying air, as already described by Surki et al. (2012), also for soybean seeds, upon manifesting the interference of both factors on the dynamic of the reserves during seedling development.

The daily loss brought about by the temperature of $70{ }^{\circ} \mathrm{C}$, for example, was twice that observed for seeds dried at $40{ }^{\circ} \mathrm{C}$, indicating the prejudicial effects on the capacity for transferring reserves for growth of the embryonic axis in seeds dried at high temperatures and then stored. Possibly, reduction in the initial quality of the lots attributed to the increase in temperature may have increased the susceptibility of the seeds to deterioration during storage, negatively affecting accumulation of dry matter during the seedling phase. In this respect, with the increase in drying temperature and in storage time, the mechanisms directly connected with the processes of 
translocation and transformation of cotyledonary reserves into substances that can be assimilated by the embryonic axis were affected, restricting the accumulation of dry matter coming from the cotyledons.

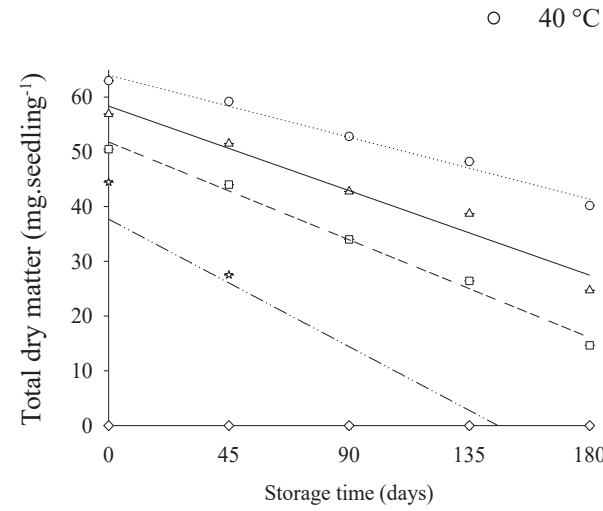

(a)

$\mathrm{TDM}_{40}{ }^{\circ} \mathrm{C}=64.0050-0.1258 \mathrm{TA} \quad\left(\mathrm{R}^{2}=0.9811\right)$ $\mathrm{TDM}_{50{ }^{\circ} \mathrm{C}}=58.3500-0.1716 \mathrm{TA} \quad\left(\mathrm{R}^{2}=0.9507\right)$ $\mathrm{TDM}_{60}{ }^{\circ} \mathrm{C}=51.7800-0.1984 \mathrm{TA} \quad\left(\mathrm{R}^{2}=0.9883\right)$ $\mathrm{TDM}_{70}{ }^{\circ} \mathrm{C}=37.6950-0.2588 \mathrm{TA} \quad\left(\mathrm{R}^{2}=0.7314\right)$ $\mathrm{TDM}_{80}{ }^{\circ} \mathrm{C}=0$

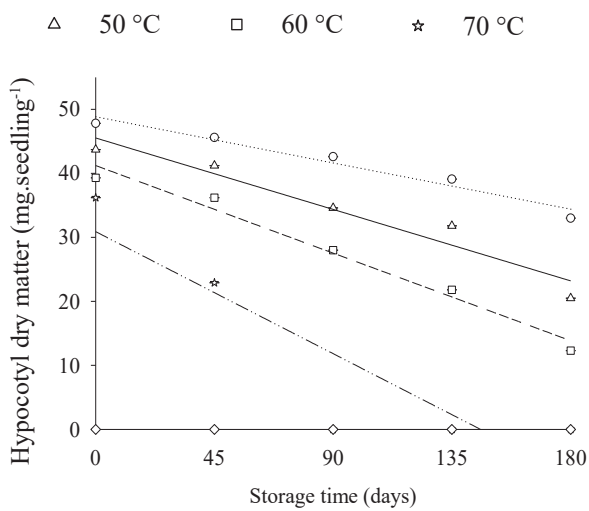

(b)

$\mathrm{HDM}_{40}{ }^{\circ} \mathrm{C}=48.8400-0.0802 \mathrm{TA} \quad\left(\mathrm{R}^{2}=0.9476\right)$ $\mathrm{HDM}_{500^{\circ} \mathrm{C}}=45.5200-0.1240 \mathrm{TA} \quad\left(\mathrm{R}^{2}=0.9144\right)$ $\mathrm{HDM}_{60}{ }^{\circ} \mathrm{C}=41.2000-0.1520 \mathrm{TA} \quad\left(\mathrm{R}^{2}=0.9698\right)$ $\mathrm{HDM}_{70}{ }^{\circ} \mathrm{C}=30.8800-0.2118 \mathrm{TA} \quad\left(\mathrm{R}^{2}=0.7324\right)$ $\mathrm{HDM}_{80}{ }^{\circ} \mathrm{C}=0$

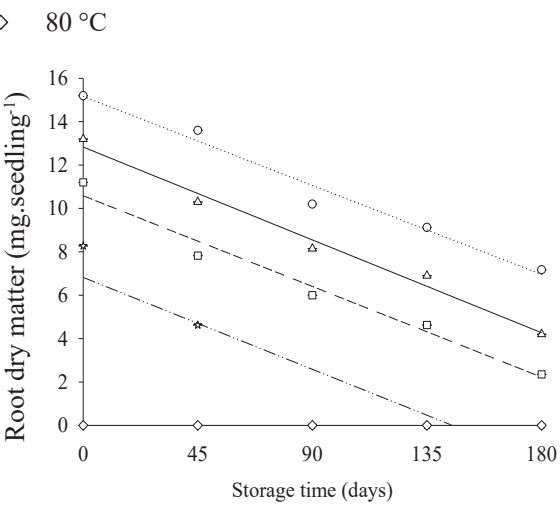

(c)

$\mathrm{RDM}_{40}{ }^{\circ} \mathrm{C}=15.1650-0.0456 \mathrm{TA} \quad\left(\mathrm{R}^{2}=0.9679\right)$ $\mathrm{RDM}_{50{ }^{\circ} \mathrm{C}}=12.8300-0.0476 \mathrm{TA} \quad\left(\mathrm{R}^{2}=0.9801\right)$ $\mathrm{RDM}_{60}{ }^{\circ} \mathrm{C}=10.5800-0.0464 \mathrm{TA} \quad\left(\mathrm{R}^{2}=0.9672\right)$ $\mathrm{RDM}_{70}{ }^{\circ} \mathrm{C}=6.8150-0.0471 \mathrm{TA} \quad\left(\mathrm{R}^{2}=0.7232\right)$ $\mathrm{RDM}_{80}{ }^{\circ} \mathrm{C}=0$

Figure 5. Results of the total dry matter of the seedling (a) and of its structures, the hypocotyl (b) and root (c), of soybean seeds subjected to different drying temperatures as a function of storage time.

\section{Conclusions}

The increase in the temperature of drying air above $40{ }^{\circ} \mathrm{C}$ affects seedling performance, and this effect is accentuated over the time of storage, above all on root growth.

The air temperature of $40{ }^{\circ} \mathrm{C}$ can be recommended for drying soybean seeds along with a storage period of 180 days under storage conditions that are not climate controlled.

\section{Acknowledgements}

To the Coordenação de Aperfeiçoamento de Pessoal de Nível Superior (Capes) and the Fundação de Apoio ao Desenvolvimento do Ensino, Ciência e Tecnologia do Estado de Mato Grosso do Sul (Fundect), due the financial support for research.

\section{References}

AFRAKHTEH, S.; FRAHMANDFAR, E.; HAMIDI, A., RAMANDI, H.D. Evaluation of growth characteristics and seedling vigor in two cultivars of soybean dried under different temperature and fluidized bed dryer. International Journal of Agriculture and Crop Sciences, v.5, n.21, p.25372544, 2013.http://ijagcs.com/wp-content/uploads/2013/09/2537-2544.pdf

BARBOSA, R.M.; VIEIRA, B.G.T.L.; MARTINS, C.C.; VIEIRA, R.D. Qualidade fisiológica e sanitária de sementes de amendoim durante o processo de produção. Pesquisa Agropecuária Brasileira, v.49, n.12, p.977-985, 2014. http://seer.sct.embrapa.br/index.php/pab/article/view/19217/12839
BARROZO, M.A.S.; MUJUMDAR, A.; FREIRE, J.T. Air-Drying of seeds: A review. Drying Technology: An International Journal, v.32, n.10, p.1127-1141, 2014. http://www.tandfonline.com/doi/pdf/10.1080/07373937.2014.915220

BENINCASA, M.M.P. Análise de crescimento de plantas: noções básicas 2.ed. Jaboticabal: FUNEP, 2003. 41p.

BESSA, J.F.V.; DONADON, J.R.; RESENDE, O.; ALVES, R.M.V.; SALES, J.F.; COSTA, L.M. Armazenamento do crambe em diferentes embalagens e ambientes: parte I - qualidade fisiológica. Revista Brasileira de Engenharia Agrícola e Ambiental, v.19, n.3, p.224-230, 2015.http://www.agriambi.com. br/revista/v19n03/v19n03a05.pdf

BRASIL. MAPA, Instrução Normativa $n^{\circ} 45$, de 17 de setembro de 2013 Padrões de Identidade e Qualidade para a produção e a comercialização de sementes. Seção 1. Ministério da Agricultura, Pecuária e Abastecimento. Diário Oficial da União de 20/09/2013. Brasília. http://www.abrasem. com.br/wp-content/uploads/2012/10/Instrução-Normativa-no ${ }^{\circ}$-45-de-17-deSetembro-de-2013-Padrões-de-Identidade-e-Qualiidade-Prod-e-Comerc-deSementes-Grandes-Culturas-Republicação-DOU-20.09.13.pdf

BRASIL. Ministério da Agricultura, Pecuária e Abastecimento. Regras para análise de sementes. Ministério da Agricultura, Pecuária e Abastecimento. Secretaria de Defesa Agropecuária. Brasília: MAPA/ACS, 2009. 395p. http:// www.agricultura.gov.br/arq_editor/file/2946_regras_analise_sementes.pdf

CHAUHAN, K.P.S. The incidence of deterioration and its localization in aged seeds of soybean and barley. Seed Science and Technology, v.13, n.3, p.769-773, 1985.

CARVALHO, E.R.; OLIVEIRA, J.A.; MAVAIEIE, D.P.R.; SILVA, H.W.; LOPES, C.G.M. Pre-packing cooling and types of packages in maintaining physiological quality of soybean seeds during storage. Journal of Seed Science, v.38, n.2, p.129-139, 2016. http://dx.doi.org/10.1590/2317$1545 \mathrm{v} 38 \mathrm{n} 2158956$ 
CORREAA, P.C.; MACHADO, P.F.; ANDRADE, E.T. Cinética de secagem e qualidade de grãos de milho-pipoca. Ciência e Agrotecnologia, v.25, n.1, p.134-142, 2001. http://www.editora.ufla.br/index.php/revistas/ciencia-eagrotecnologia/artigos-publicados/10-volumes-revista/53-vol25numero1

COSTA, J.A.; PIRES, J.L.F.; THOMAS, A.L.; ALBERTON, M. Comprimento e índice de expansão radial do hipocótilo de cultivares de soja. Ciência Rural, v.29, n.4, p.609-612, 1999.http://www.scielo.br/pdf/cr/v29n4/a06v29n4.pdf

DELIBERALI， J.; OLIVEIRA， M.; DURIGON， A.; DIAS， A.R.G.; GUTKOSKI, L.C.; ELIAS, M.C. Efeitos de processo de secagem e tempo de armazenamento na qualidade tecnológica de trigo. Ciência e Agrotecnologia, v.34, n.5, p.1285-1292, 2010.http://www.scielo.br/pdf/cagro/v34n5/29.pdf

DIOS, C.A.D. Recomendaciones sobre el manejo y poscosecha del girasol. Pergamino: Estación Experimental Agropecuária de Pergamino, INTA, p.251-261, 1984 .

FARIA, R.Q.; TEIXEIRA, I.R.; CUNHA, D.A.; HONORATO, J.M.; DEVILLA, A. Qualidade fisiológica de sementes de crambe submetidas à secagem. Revista Ciência Agronômica, v.45, n.3, p.453-460, 2014.http:// www.ccarevista.ufc.br/seer/index.php/ccarevista/article/view/2306/971

FEHR, W.R.; CAVINESS, C.E. Stages of soybean development. Special Report, n.80, Ames: Iowa State University of Science and Technology, 1977. 11p.

FERREIRA, A.G.; BORGHETTI, F. (Orgs.). Germinação: do básico ao aplicado. Porto Alegre: Artmed, 2004. 324p.

FERREIRA, D.F. Sisvar: um sistema computacional de análise estatística. Ciência e Agrotecnologia, v.35, n.6, p.1039-1042, 2011. http://www.scielo. $\mathrm{br} / \mathrm{pdf} / \mathrm{cagro} / \mathrm{v} 35 \mathrm{n} 6 / \mathrm{a} 01 \mathrm{v} 35 \mathrm{n} 6 . \mathrm{pdf}$

FRANÇA-NETO, J.B.; KRZYZANOWSKI, F.C.; HENNING, A.A.; PÁDUA, G.P. Tecnologia da produção de semente de soja de alta qualidade. Informativo ABRATES, v.20, n.3, p.26-32, 2010.

GARCIA, D.C.; BARROS, A.C.S.A.; PESKE, S.T.; MENEZES, N.L. A secagem de sementes. Ciência Rural, v.34, n.2, p.603-608, 2004.http://www. scielo.br/pdf/cr/v34n2/a45v34n2.pdf

HENNING, F.A.; MERTZ, L.M.; JACOB JUNIOR, E.A.; MACHADO, R.D.; FISS, G.; ZIMMER, P.D. Composição química e mobilização de reservas em sementes de soja de alto e baixo vigor. Bragantia, v.69, n.3, p.727-734, 2010. http://www.scielo.br/pdf/brag/v69n3/26.pdf

MAHJABIN, S.B.; ABIDI, A.B. Physiological and biochemical changes during seed deterioration: a review. International Journal of Recent Scientific Research, v.6, n.4, p.3416-3422, 2015. http://www.recentscientific.com/sites/ default/files/2185.pdf

MAIA, A.R.; LOPES, J.C.; TEIXEIRA, C.O. Efeito do envelhecimento acelerado na avaliação da qualidade fisiológica de sementes de trigo. Ciência e Agrotecnologia, v.31, n.3, p.678-684, 2007. http://www.scielo.br/pdf/cagro/ v31n3/a12v31n $3 . p d f$

MARCOS-FILHO, J. Fisiologia de sementes de plantas cultivadas. 2ed. Londrina, PR: ABRATES, 2015. 660p.

MARCOS-FILHO, J. Importância do potencial fisiológico da semente de soja. Informativo ABRATES, v.23, n.1, p.21-24, 2013.http://www.abrates.org. br/images/Informativo/v23_n1/02._Julio_Importancia_Fisiologia.pdf

MBOFUNG, G.C.Y.; GOGGI, A.S.; LEANDRO, L.F.S.; MULLEN, R.E. Effects of storage temperature and relative humidity on viability and vigor of treated soybean seeds. Crop Science, v.53, n.3, p.1086-1095, 2013.https:// dl.sciencesocieties.org/publications/cs/articles/53/3/1086
MENEZES, N.L.; CICERO, S.M.; VILLELA, F.A.; BORTOLOTTO, R.P. Using $\mathrm{x}$-rays to evaluate fissures in rice seeds dried artificially. Revista Brasileira de Sementes, v.34, n.1, p.70-77, 2012a. http://www.scielo.br/pdf/ $\mathrm{rbs} / \mathrm{v} 34 \mathrm{n} 1 / \mathrm{a} 09 \mathrm{v} 34 \mathrm{n} 1 . \mathrm{pdf}$

MENEZES, N.L.; PASQUALLI, L.L.; BARBIERI, A.P.P.; VIDAL, M.D.; CONCEIÇÃO, G.M. Temperaturas de secagem na integridade física, qualidade fisiológica e composição química de sementes de arroz. Pesquisa Agropecuária Tropical, v.42, n.4, p.430-436, 2012b.https://www.revistas.ufg.br/index.php?journal=pat\&page $=$ article\&op=view\&path $\% 5 \mathrm{~B} \% 5 \mathrm{D}=18457 \&$ path $\% 5 \mathrm{~B} \%$ $5 \mathrm{D}=12715$

MENGARDA, L.H.G.; LOPES, J.C.; ZANOTTI, R.F.; ALEXANDRE, R.S. Desempenho de genótipos de mamoeiro quanto à qualidade física e fisiológica de sementes e análises de diversidade. Bioscience Journal, v.31, n.3, p.719-729, 2015.http://www.seer.ufu.br/index.php/biosciencejournal/ article/view/23852/16457

NAKAGAWA, J. Teste de vigor baseados no desempenho de plântulas. In: KRZYZANOWSKI, F.C.; VIEIRA, R.D.; FRANÇA-NETO, J.B. (Eds.). Vigor de sementes: conceitos e testes. Londrina: ABRATES, 1999. p.2-1 a 2-24.

PARAGINSKI, R.T.; ROCKENBACH, B.A.; SANTOS, R.F.; ELIAS, M.C.; OLIVEIRA, M. Qualidade de grãos de milho armazenados em diferentes temperaturas. Revista Brasileira de Engenharia Agrícola e Ambiental, v.19, n.4 p.358-363, 2015.http://www.agriambi.com.br/revista/v19n04/v19n04a09.pdf

PEREIRA, W.A.; PEREIRA, S.M.A.; DIAS, D.C.F.S. Dynamics of reserves of soybean seeds during the development of seedlings of different commercial cultivars. Journal of Seed Science, v.37, n.1, p.63-69, 2015. http://dx.doi. org/10.1590/2317-1545v37n1142202

PEREIRA, W.A.; PEREIRA, S.M.A.; DIAS, D.C.F.S. Influence of seed size and water restriction on germination of soybean seeds and on early development of seedlings. Journal of Seed Science, v.35, n.3, p.316-322, 2013. http://www. scielo.br/pdf/jss/v35n3/07.pdf

PESKE, S.T.; BAUDET, L.M.; VILLELA, F.A. Tecnologia de pós-colheita para sementes. In: SEDIYAMA, T. (Ed.) Tecnologias de produção de sementes de soja. Londrina. 2013. p.327-344.

RATHINAVEL, K. Influence of storage temperature and seed treatments on viability of cotton seed (Gossypium hirsutum L.). Cotton Research Journal, v.6, n.1, p.1-6, 2014. http://www.cicr.org.in/isci/6-1/Paper_1.pdf

RESENDE, O.; ALMEIDA, D.P.; COSTA, L.M.; MENDES, U.C.; SALES, J.F. Adzuki beans (Vigna angularis) seed quality under several drying conditions. Ciência e Tecnologia de Alimentos, v.32, n.1, p.151-155, 2012. http://www.scielo.br/pdf/cta/v32n1/aop cta 5007.pdf

SCHUH, G.; GOTTARDI, R.; FERRARI FILHO, E.; ANTUNES, L.E.G.; DIONELLO, R.G. Efeitos de dois métodos de secagem sobre a qualidade físico-química de grãos de milho safrinha - RS, armazenados por 6 meses. Semina: Ciências Agrárias, v.32, n.1, p.235-244, 2011.http://www.uel.br/ revistas/uel/index.php/semagrarias/article/view/3601/7190

SILVA, P.A.; DINIZ, K.A.; OLIVEIRA, J.A.; VON PINHO, E.V.R. Análise fisiológica e ultra-estrutural durante o desenvolvimento e a secagem de sementes de soja. Revista Brasileira de Sementes, v.29, n.2, p.15-22, 2007. http://www.scielo.br/pdf/rbs/v29n2/v29n2a03.pdf

SMANIOTTO, T.A.S.; RESENDE, O.; MARÇAL, K.A.F.; OLIVEIRA, D.E.C.; SIMON, G.A. Qualidade fisiológica das sementes de soja armazenadas em diferentes condições. Revista Brasileira de Engenharia Agricola e Ambiental, v.18, n.4, p.446-453, 2014. http://www.agriambi.com. br/revista/v18n04/v18n04a13.pd f 
SURKI, A.A.; SHARIFZADEH, F.; AFSHARI, R.T. Effect of drying conditions and harvest time on soybean seed viability and deterioration under different storage temperature. African Journal of Agricultural Research, v.7, n.36, p.5118-5127, 2012. http://www.academicjournals.org/journal/AJAR/ article-full-text-pdf/D9AEAAA35317

TIECKER JUNIOR, A.; GUIMARÃES, L.E.; FERRARI FILHO, E.; CASTRO, B.; DEL PONTE, E.M.; DIONELlO, R.G. Qualidade físicoquímica de grãos de milho armazenados com diferentes umidades em ambientes hermético e não hermético. Revista Brasileira de Milho e Sorgo, v.13, n.2, p.174-186, 2014.http://rbms.cnpms.embrapa.br/index.php/ojs/ article/view/484/pdf_93

ULLMANN, R.; RESENDE, O.; CHAVES, T.H.; OLIVEIRA, D.E.C.; COSTA, L.M. Qualidade fisiológica das sementes de sorgo sacarino submetidas à secagem em diferentes condições de ar. Revista Brasileira de Engenharia Agrícola e Ambiental, v.19, n.1, p.64-69, 2015. http://www. agriambi.com.br/revista/v19n01/v19n01a11.pdf

ULLMANN, R.; RESENDE, O.; SALES, J.F.; CHAVES, T.H. Qualidade das sementes de pinhão manso submetidas à secagem artificial. Revista Ciência Agronômica, v.41, n.3, p. 442-447, 2010. http://www.ccarevista.ufc.br/seer/ index.php/ccarevista/article/view/911/463
VANZOLINI, S.; ARAKI, C.A.S.; SILVA, A.C.T.M.; NAKAGAWA, J. Teste de comprimento de plântula na avaliação da qualidade fisiológica de sementes de soja. Revista Brasileira de Sementes, v.29, n.2, p.90-96, 2007. http://www.scielo.br/pdf/rbs/v29n2/v29n2a12.pdf

VENANCIO, L.P.; LOPES, J.C.; MACIEL, K.S.; COLA, M.P.A. Teste do envelhecimento acelerado para avaliação da qualidade fisiológica de sementes de milho. Enciclopédia Biosfera, v.8, n.14, p.899- 906, 2012. http:// www.conhecer.org.br/enciclop/2012a/agrarias/teste\%20do.pdf

VIEIRA, B.G.T.L.; BARBOSA, G.F.; BARBOSA, R.M.; VIEIRA, R.D Structural changes in soybean seed coat due to harvest time and storage. Journal of Food, Agriculture \& Environment, v.11, n.1, p.625-628, 2013a http://world-food.net/download/journals/2013-issue_1/2013-issue_1agriculture/67.pdf

VIEIRA, R.D.; PANOBIANCO, M.; MARCOS-FILHO, J. Avaliação do potencial fisiológico de sementes. In: SEDIYAMA, T. (Ed.). Tecnologias de produção de sementes de soja. Londrina: ed. Mecenas, 2013b. p.109-127. 